\title{
Does Female Education Promote Economic Performance? Evidence from Nigeria
}

\author{
Risikat Oladoyin S. Dauda \\ Correspondence: Risikat Oladoyin S. Dauda, Department of Economics, University of Lagos, Akoka, Yaba, \\ Lagos, Nigeria. E-mail: rdauda@unilag.edu.ng
}

Received: July 9, 2012 Accepted: November 20, $2012 \quad$ Online Published: December 10, 2012

doi:10.5539/ijef.v5n1p201～URL: http://dx.doi.org/10.5539/ijef.v5n1p201

\begin{abstract}
The paper examines whether female education promotes economic performance in Nigeria, using the co-integration and error correction techniques for the period 1975-2008. The augmented Solow model is used to incorporate the gender dimension. The unit root tests conducted indicated that all variables are stationary at first difference and are also co-integrated. This shows that a long-run equilibrium relationship exists among them. Furthermore, it was revealed that the male education has a significant and positive impact on the Nigerian economy, while female education does not. Contrary to expectations, the results also revealed that investment to GDP ratio and government investment on social and community services have no significant effect on real GDP when lagged by one year. It is implied that instead of promoting growth, investment efforts have not been beneficial to the economy. The result shows that trade openness is an effective policy for promoting economic performance in Nigeria. The policy implication of the study is that if the country wants to achieve sustainable growth which would engender structural transformation of the Nigerian economy, the issue of gender equality in access to education should be taken seriously. Thus, government should pay more attention to educational policies that enhance female enrolment rates, participation in educational institutions and literacy in order to enhance women contribution to growth and economic transformation in Nigeria. This should be done in a stable macroeconomic environment which has a tendency to enhance domestic investment in Nigeria.
\end{abstract}

Keywords: female education, gender, economic growth, human capital, Nigeria

\section{Introduction}

Education is considered as a major contributing factor to sustainable development and poverty alleviation in developing countries, including Nigeria. Thus, the need for the promotion of gender equality in education is highly essential for growth and structural transformation of an economy and the attainment of economic development. The education of women is instrumental to the reduction of fertility rates and population growth rates. It also enables them to engage in healthier habits and bring their children up in healthy ways. Female education is highly important in reducing both maternal and child mortalities, which increases life expectancy (World Bank, 2001; Herz and Sperling, 2004).

Nigeria's economic performance in the last four decades leaves much to be desired. The country's economic performance is dependent on the performance of oil in the world oil market. This has culminated in a series of booms and depressions over the years. Since the introduction of democracy 1999, Nigeria has been experiencing modest economic growth, driven mainly by the non-oil sector. However, the oil boom and associated income derived from oil exports have not translated into sustainable development and wealth for its citizens. The major challenges facing the country's social and economic development are the weak infrastructure base, especially power and transport infrastructure, corruption, macro-economic instability, over-dependence on oil revenues, poor governance and educational gender gap. The need to bridge the gender inequality in access to productive resources has been a major concern in Nigeria, especially, since the 1985 Nairobi Declaration and World Declaration on Education for All. Gender mainstreaming in all policies, programmes and organizational cultures through the incorporation of the principles of Convention on the Elimination of all forms of Discrimination against Women (CEDAW) has become a central principle of development programmes and strategies.

In recent times, Nigerian women have been contributing significantly to the development of the various sectors of the economy. Many women have been able to distinguish themselves in major corporations, such as Nigerian Stock Exchange (NSE), the National Agency for Food Drugs Administration and Control (NAFDAC), Economic 
and Financial Crimes Commission (EFCC) and in ministerial positions at the federal and state levels. This new development has given rise to calls for the education of women in the country.

Consequently, increasing attention is now being paid to the promotion of women education. It has been acclaimed that improving the education of women alongside that of men may be the most efficient way to reduce poverty and ensure rapid growth and structural transformation. Although, there have been quite a number of empirical studies on the relationship between educational human capital and economic growth in Nigeria, very few of them focus on the growth impact of female education. This is clearly the motivation behind this study. The paper is also important for Nigeria because it tends to broaden our understanding of this important issue and provides guidance on how to make progress.

Against this background, the main objective of this paper, therefore, is to provide quantitative evidence on the relationship between female education and Nigeria's economic performance. Specifically, it sheds light on the role of female education in the growth and transformation process in Nigeria. The rest of the paper is structured as follows: Section two provides a review of literature. This is followed by a presentation of the stylized facts on female education in Nigeria's development. Section three outlines the analytical framework and the model while section four contains the empirical results. Section five concludes the paper.

\section{Literature Review}

There have been a number of theoretical and empirical studies which suggest that female education has enormous economic and social benefits. Herz and Sperling (2004) provide extensive evidence from developing countries in widely different circumstances on the returns to girls' education and these were subdivided into four broad categories. They are briefly summarized. Regarding the nexus between female education and women empowerment, a strong and extensive body of evidence suggests that education enhances women's bargaining position in both the family and society (Barro 1999; Sen, 2000). The second benefit is that female education encourages smaller, healthier, better-educated families (World bank, 2001; Hill and King, 1995). The third benefit shows that education can be one of the best defenses against HIV/AIDS, both because of education's impact on women's earning capacity, empowerment, and family well-being, and because school-based HIV education programs discourage risky behavior among young girls in particular (UNESCO, 2002). The fourth relates to the growth impact of female education. It is widely believed that education generally leads to increased income and productivity, for individuals and for nations as a whole.

A number of empirical growth studies incorporating female education yield mixed results (Barro and Lee 1996; Knowles, Lorgelly and Owen 2002; Galor and Weil 1996; Hill and King 1995; among others). These studies found that both male and female schooling have differential impact on GDP per capita. Dollar and Gatti (1999), in a 100-country World Bank study also found that the gender gap in education disappears with development, while efforts to educate girls boost the pace of development and in turn promote education. The study revealed that increasing the share of women with secondary education by 1 percentage point boosts annual per capita income growth by 0.3 percentage points.

Klasen (2002) investigated the nexus between gender inequality in education and long-term economic growth by using cross-country and panel regressions during 1960-1992. The author found that gender inequality in education directly affects economic growth lowering the average level of human capital and indirectly through its impact on investment and population growth. The results however differ by regions. Klasen and Lamanna (2008) also lend credence to this fact. In a study carried out by Cooray and Mallick (2011), it was found that the impact of human capital disaggregated by gender has a differential impact on economic growth. Male human capital showed a positive and significant effect on growth while female human capital has no significant effect when the openness variables are considered. Zaman (2010) seeks to establish whether there is any causal relationship between female enrolment rates and economic growth in Pakistan using co-integration and Granger causality test during the period 1966-2008. The study supports the unidirectional causality relationship between the GDP and female enrolment within the specific context of Pakistan.

There are many studies on the growth impact of human capital in Nigeria, but the specific relationship between female education and the performance of the Nigerian economy has not been adequately analyzed. However, it is noteworthy that some studies have demonstrated the importance of female education in poverty reduction. For instance, Anyanwu cited in Odusola (1998) showed that good health status and educational attainment of Nigerian women positively influenced their income in six Nigerian states, namely, Anambra, Borno, Cross River, Ogun, Plateau and Sokoto. The coefficients of primary, secondary and technical school attainment were statistically significant at 5 percent level while that of excellent health conditions was significant at 1 percent. 
Okojie (1995) also demonstrated the positive effects of female educational advancement on poverty reduction which invariably translate into economic growth and development.

A major conclusion that has emerged from the review of literature is that diverse opinions exist concerning the impact of female education on growth. While some studies lean towards a positive effect of female education on growth, others have shown negative effect. But most studies lend credence to the fact that promotion of female education pays off substantially.

\subsection{Stylized Facts on Female Education in Nigerian Development}

Education in Nigeria is provided by both the public and private sector with planning, administration and funding from the three tiers of government, federal, state and local. The Nigerian government accords high priority to female education. Towards this end, a great number of policies, programmes and strategies for enhancing female education were put in place. These among others include, the Blueprint on Women Education launched in 1986 to re-orientate the attitude of all females irrespective of age towards education in the fields of science, technology and mathematics. Family Support Basic Education Programme launched in 1994 to encourage girl-child education, The Universal Basic Education (UBE) scheme designed to ensure the access of all children in Nigeria to primary and junior secondary school level of education was launched in 1999. The UBE was meant to overcome geographical and gender disparities as well as address the issue of capacity building of teachers, structural state of schools and availability of instructional materials.

Furthermore, the Girls' Education Project was launched by the Federal Government of Nigeria, Department for International Development (DFID) and United Nations Children's Fund (UNICEF) in 2004 and currently under implementation. Its main goal is to achieve significant progress in Nigeria towards Millennium Development Goal 3: 'to eliminate gender disparity in primary and secondary education preferably by 2005 and to all levels of education no later than 2015'. The introduction of these programmes has made a major impact on enrolment and the number of schools. Figures 1-3 presented in the appendix show phenomenal growth in the number of students in Nigerian educational institutions during the period 1979-2008. Figure 1 shows the predominance of male enrolment at primary school. In the same vein, female secondary school and tertiary institutions enrolment increased dramatically during the same period. The general trend at secondary and tertiary levels of education also shows a lower enrolment rate for girls than boys.

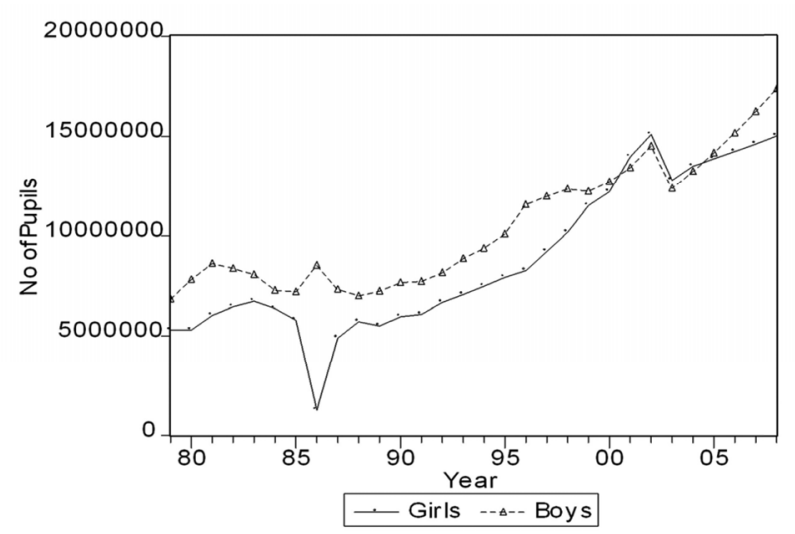

Figure 1. Primary School Enrolment, 1979-2008 


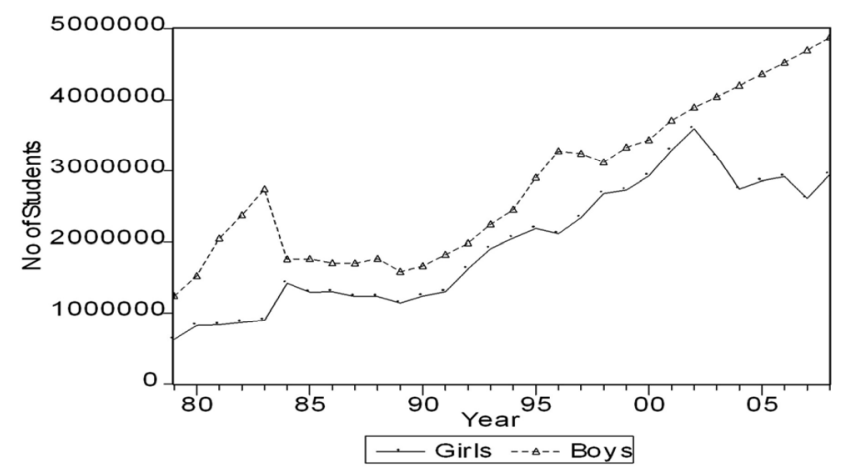

Figure 2. Secondary school Enrolment, 1979-2008

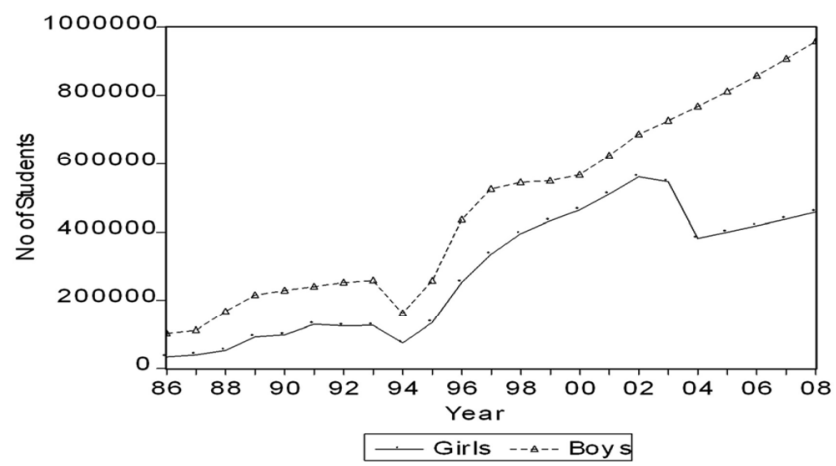

Figure 3. Total Enrolment in Nigerian Universities, 1986-2008

Another glaring fact from available statistics is the fact that women have much lower literacy rate than men. This is evident in Table 1 which displays gender inequality in education indicators for Nigeria and some selected countries.

Table 1. Gender Inequality in Education Indicators for SANE Countries, 2004-2009

\begin{tabular}{|c|c|c|c|c|c|}
\hline $\mathbf{S} / \mathbf{N}$ & Indicators & Nigeria & Algeria & Egypt & South Africa \\
\hline 1 & Adult literacy rate, females as a $\%$ of males, $2005-2008$ & 68 & 79 & 77 & 98 \\
\hline \multirow[t]{3}{*}{2.} & Youth (15-24) literacy rate, 2004-2008, (\%): & & & & \\
\hline & - Male & 78 & 94 & 88 & 96 \\
\hline & - Female & 65 & 89 & 82 & 98 \\
\hline \multirow[t]{3}{*}{3.} & Gross primary school enrolment ratio, 2005-2009, (\%): & & & & \\
\hline & - Male & 99 & 111 & 102 & 106 \\
\hline & - Female & 87 & 104 & 97 & 103 \\
\hline \multirow[t]{3}{*}{4} & Net primary school enrolment ratio, 2005-2009, (\%): & & & & \\
\hline & -Male & 64 & 96 & 95 & 87 \\
\hline & -Female & 58 & 94 & 92 & 88 \\
\hline \multirow[t]{3}{*}{5.} & Net primary school attendance ratio, 2005-2009, (\%): & & & & \\
\hline & -Male & 65 & 97 & 96 & 80 \\
\hline & -Female & 60 & 96 & 94 & 83 \\
\hline \multirow[t]{3}{*}{6.} & Gross secondary school enrolment ratio, 2005-2009, (\%): & & & & \\
\hline & -Male & 34 & 80 & 82 & 93 \\
\hline & -Female & 27 & 86 & 77 & 97 \\
\hline \multirow[t]{3}{*}{7.} & Net secondary school enrolment ratio, 2005-2009, (\%): & & & & \\
\hline & -Male & 29 & 65 & 73 & 70 \\
\hline & -Female & 22 & 68 & 69 & 74 \\
\hline \multirow[t]{3}{*}{8.} & Net secondary school attendance ratio, 2005-2009, (\%): & & & & \\
\hline & -Male & 45 & 57 & 72 & 41 \\
\hline & -Female & 43 & 65 & 67 & 48 \\
\hline
\end{tabular}

Source: www.unicef.org/infobycountry/index.html. Accessed on 09/06/2011 
As shown in Table 1, a comparison of indicators measuring gender inequality in education in Nigeria with that of other "Africa's G-4" or the SANE (South Africa, Algeria, Nigeria and Egypt) countries that have recently been designated African "growth poles" akin to what the BRIC (Brazil, Russia, India and China) are to the developing world supports the fact that girls lagged behind in school enrolment and attendance. Nigeria has a proportion less than the other African 'growth poles' in all the education indicators during the 2004-2009 study periods. Also, women face discrimination in access to education. For instance, net secondary school enrolment ratio for female in Nigeria stood at $22 \%$ while it was $68 \%, 69 \%, 74 \%$ respectively for Algeria, Egypt and South Africa. Similarly, net secondary school attendance ratio for female was low in Nigeria. Several reasons culminate in low literacy rate among women. One of these is that most parents are biased in favour of the education of the sons at the expense of that of their daughters. These parents are often more willing to make financial sacrifices for their son's than for their daughters' education. Other factors impeding women education in Nigeria include poverty and economic issues, early marriage, teenage pregnancy, inadequate school infrastructure and cultural and religious misinterpretation. Overall, one can conclude from the trend analysis that the goal of achieving gender equality in education remains elusive and sustainable development outlook appears to be precarious.

\section{The Model, Data and Estimation Techniques}

\subsection{The Model}

The econometric approach for this study follows Cooray and Mallick (2011). It employs an extended version of the Solow growth model with real GDP being a function of investment to GDP ratio, human capital accumulation (disaggregated by gender), labour force, openness to trade and government spending on community services. This takes the following form:

$$
\ln R G D P_{t}=\beta_{0}+\beta_{1} \ln I N V G_{t}+\beta_{2} \ln I O P_{t}+\beta_{3} \ln L B F+\beta_{4} \ln M E S_{t}+\beta_{5} \ln F E S_{t}+\beta_{6} \ln G C S P+\varepsilon_{t}
$$

where RGDP is the real GDP, INVG represents investment/GDP ratio, IOP represents index of openness, MES is male human capital proxied by male enrolment at the secondary school level, FES is male human capital proxied by female enrolment at the secondary school level, LBF is labour force, GCSP is government spending on social and community services and $\varepsilon$ is a random error term. $\ln$ is logarithmic transformation.

The a priori expectations are: $\beta_{1}, \beta_{2}, \beta_{3,} \beta_{4}, \beta_{5}, \beta_{6}>0$; this implies that all the explanatory variables are expected to have positive effects on real GDP. This study provides empirical evidence on the relationship between female education and Nigeria's economic performance using the error correction methodolgy. It is a clear departure from Cooray and Mallick (2011) because instead of trying to account for per capita GDP growth rate, this study relates female education to real GDP levels.

\subsection{Data Sources}

Data were obtained from several secondary sources and covered the period 1975-2008. Data were obtained from various volumes of Annual Reports and Statement of Accounts, Statistical Bulletin published by the Central Bank of Nigeria, Annual Abstract of Statistics and Social Statistics Report of the Nigerian National Bureau of Statistics and publications of the Federal Ministry of Education, Nigeria, The World Bank, World Development Indicators and enrolment figures in Anyanwu, Oyefusi, Oaikhenan and Dimowo (1997).

\subsection{Estimation Techniques}

For the purpose of analysis, the error correction technique will be employed to analyze the relationship among the variables in our model. Estimating equation 8 by the ordinary least squares (OLS) may lead to spurious results and inferences if some of the explanatory variables and the dependent variable are non-stationary. Thus, the Augmented Dickey-Fuller unit root test is used to ascertain the characteristics of the data in order to determine whether the variables have unit roots i.e, whether it is stationary and the order of integration. Next, the Johansen Cointegration technique is used to test for the existence of a long-run relationship among variables in the equation. Mainly, it is used to check if the independent variables can predict the dependent variable both now (short-run) or in the future (long-run). Although long-run equilibrium relationship may occur among variables in the regression model, short-run equilibrium may not occur. The short-run dynamic adjustment is modeled using error correction mechanism i.e it is used to correct or eliminate the discrepancy that occurs in the short-run. The coefficient of error-correction variable gives the percentage of the discrepancy between the variables that can be eliminated in the next time period. This methodology is employed because it adds richness, flexibility and versatility to the econometric modeling and integrates short-run dynamics with long-run equilibrium relationships between the variables, while at the same time correcting for short-term disequilibrium. This facilitates accurate predictions of the economic relationships between the variables. 


\section{Empirical Results and Discussion}

Table 2, shows the results of the unit root test. These results depict that some of the variables were non-stationary in their level, but after first differencing, all variables attained stationarity. This can be seen by comparing the observed values (in absolute terms) of the ADF tests with the critical values (in absolute terms) of the test statistics. By implication, this suggests the acceptance of the null hypothesis and it is necessary to conclude that there is the presence of a unit root in the series.

Table 2. Results of Unit-Root Test

\begin{tabular}{lllllll}
\hline \multicolumn{2}{l}{ Augmented Dickey-Fuller Test } & \multicolumn{2}{l}{ Order of Integration } \\
\cline { 1 - 3 } Variables & Intercept & Intercept and Trend & & Intercept & Intercept and Trend & \\
${$\cline { 1 - 2 }$} }$ & 1.2097 & -1.2903 & $-3.7502^{*}$ & $-4.3491^{*}$ & $\mathrm{I}(1)$ \\
INVG & -2.1387 & -2.2577 & $-4.5028^{*}$ & $-4.5909^{*}$ & $\mathrm{I}(1)$ \\
IOP & -2.1234 & -2.3573 & $-4.2624^{*}$ & $-4.2084^{*}$ & $\mathrm{I}(1)$ \\
LNFES & $-4.4223^{*}$ & $-3.7989^{*}$ & -2.2843 & -2.6924 & $\mathrm{I}(0)$ \\
LNMES & -1.7014 & -2.7605 & $-3.2586^{*}$ & -3.1447 & $\mathrm{I}(1)$ \\
LNLBF & 0.0983 & -2.6005 & -2.1976 & $-3.5755^{*}$ & $\mathrm{I}(1)$ \\
LNGCSP & 0.7039 & $-3.4435^{* * *}$ & $-5.4957^{*}$ & $-4.59443^{*}$ & $\mathrm{I}(0)$ \\
\hline
\end{tabular}

Note: $(*),(* *),(* *)$ indicates significant at $1 \%, 5 \%$ and $10 \%$ level respectively.

MacKinnon (1996) critical value for rejection of hypothesis of unit root test was applied.

Source: Author's Estimation Using E-view 5.0

The Johansen maximum likelihood test for co-integration was used to carry out the co-integration test. The Max-Eigen value test was employed in determining the number of co-integrating relations in the series. The result is contained in Table 3. From the table, there was an evidence of at most three co-integrating equations at $5 \%$. By implication, this means that there is co-integration among the variables in the long-run. This is an evidence of a long-run relationship among the variables in the model.

Table 3. Results of the Johansen Cointegration Test

\begin{tabular}{cllcc}
\hline Hypothesized & $\begin{array}{l}\text { Eigenvalue } \\
\text { No. Of CE(s) }\end{array}$ & Trace Statisics & $\begin{array}{l}0.05 \\
\text { Critical Value }\end{array}$ & Prob** \\
\hline None * & 0.933801 & 212.7789 & 125.6154 & 0.0000 \\
At most 1 & 0.768815 & 125.8962 & 95.75366 & 0.0001 \\
At most 2 & 0.636088 & 79.03101 & 69.81889 & 0.0077 \\
At most 3 & 0.411330 & 46.68405 & 47.85613 & 0.0641 \\
At most 4 & 0.375789 & 29.72758 & 29.79707 & 0.0509 \\
At most 5 & 0.365173 & 14.64702 & 15.49471 & 0.0668 \\
At most 6 & 0.003311 & 0.106138 & 3.841466 & 0.7446 \\
\hline
\end{tabular}

Trace test indicates 3 cointegrating eqn(s) at the 0.05 level

$*$ denotes rejection of the hypothesis at $5 \%$ level

**Mac Kinnon-Haug-Michelis (1999) p-values

Source: Author's Estimation Using E-view 5.0

The main focus of this paper is to empirically determine the impact of female education on economic growth in Nigeria. The empirical results of estimating equation (1) are presented in Table 4. The standard error of the regression, the $t$-values, the coefficient of multiple determination $\left(R^{2}\right)$, F-ratio, Schwarz criterion and the Durbin-Watson statistics are shown in the table. 
Table 4. Error Correction Model Estimates

Dependent Variable: D (LNRGDP)

\begin{tabular}{lcccc}
\hline Variables & Coefficient & Std. Error & t-Statistic & Prob. \\
\hline D(INVG(-1)) & -0.005171 & 0.003587 & -1.441301 & 0.1630 \\
D(IOP) & 0.254332 & 0.106172 & $2.395464 * *$ & 0.0251 \\
D(IOP(-1)) & 0.333610 & 0.125193 & $2.664764 * *$ & 0.0138 \\
LNFES(-1) & 0.029282 & 0.020979 & 1.395795 & 0.1761 \\
LNGSCP & 0.007622 & 0.009587 & 0.795006 & 0.4347 \\
D(LNLBF) & -8.382009 & 4.113438 & $-2.037714^{* *}$ & 0.0532 \\
D(LNMES) & 0.231579 & 0.106709 & $2.170190^{* *}$ & 0.0406 \\
ECM(-1) & -0.275004 & 0.140595 & $-1.955998^{* *}$ & 0.0627 \\
C & -0.238928 & 0.286172 & -0.834909 & 0.4124 \\
\hline Adjusted R-squared & 0.537855 & & & \\
Schwarz criterion & -2.310187 & & & \\
Durbin-Watson stat 1.813552 & & & \\
F-statistic & & & \\
\hline * **, means 1\%, 5\% level of significance & & & \\
\hline
\end{tabular}

Source: Author's Estimation Using E-view 5.0

The empirical analysis shows that female education has no significant impact on real GDP in Nigeria. The findings are consistent with the findings of Barro (2001) and Cooray and Mallick (2011). This result suggests the need for investment in female human capital. The male human capital has a significant and positive effect on the Nigerian economy. This implies that the theoretical expectations that male human capital education promotes growth are valid in the Nigerian case. The coefficient of the error correction variable (ECM (-1)) is, as expected, negatively signed, statistically significant at 5 percent level and its absolute value lies between zero and unity. Consequently, it will act to correct any deviations from long-run equilibrium. The size of the absolute value of the error-correction coefficient shows that the speed of restoration to equilibrium in the event of any temporary displacement is slow.

Contrary to expectations, the results also revealed that investment to GDP ratio has a negative but not significant effect on real GDP when lagged by one year. It is implied that instead of promoting growth, investment efforts have not been beneficial to the economy. Nigeria's investment climate has not enhanced the country's purchasing power. This implied that there were severe infrastructural bottlenecks that hindered private sector initiatives. Government investment on social and community services has no significant effect on the Nigerian economy. This is not surprising because of the high level of corruption in the country. Most of the government spending on social services tends to end in private pockets. Moreover, the projects embarked upon by the government are not aimed at alleviating the suffering of the people but to score political points. The result shows that trade openness is an effective policy for promoting economic performance in Nigeria. The findings suggest that creation of a stable macroeconomic environment has a tendency to enhance domestic investment in Nigeria.

\section{Conclusion and Policy Implications}

This study has examined whether female education promotes Nigeria's economic performance using the Johansen co-integration and error correction techniques. The augmented Solow model is used to incorporate the gender dimension. In the course of this study, the relationships among some key socio and macroeconomic variables such as investment to GDP ratio, human capital accumulation (disaggregated by gender), labour force, openness to trade and government spending on social and community services and real GDP have been investigated. The Johansen maximum likelihood test for co-integration shows that there is an evidence of a long-run relationship among the variables in the model. The results of this study reveal that female education does not have any significant impact on real GDP in Nigeria. This finding brings to the fore the need for adequate investment in female education. The fact that male education has a positive and statistically significant impact on the growth of the Nigerian economy may be attributed, in part, to the biased nature of child development in many parts of Nigeria which favours the education of the male children at the expense of female children. The policy implication of the study is that if the country wants to achieve sustainable growth which would engender structural transformation of the Nigerian economy, the issue of gender equality in access to education should be taken seriously. Thus, government should reappraise, existing development policies and strategies and pay more attention to educational policies that enhance female enrolment rates, participation in 
educational institutions and literacy to enhance women contribution to growth and economic transformation in Nigeria.

\section{References}

Anyanwu, J. C., Oyefusi, A., \& Oaikhenan, H., \& Dimowo, F. A. (1997). The Structure of the Nigerian Economy. (1960-1997). Onitsha: Joanee Educational Publishers Ltd.

Asun, C. F., Baklit, G., \& Okoye, C. O. (1997). Trends in women education: an analysis of primary, secondary and university enrolment in Nigeria (1984-1993). In: Women development issues: a book of readings. Ojowu Ode (ed). Jos. University of Jos: Centre for Development Studies, 159-169

Barro, R., \& Lee, J. (1996). International Measures of Educational Achievement. American Economic Review, $86,218-223$.

Barro, R. J. (1999). Determinants of Democracy. Journal of Political Economy, 107(6), S158-83. http://dx.doi.org/10.1086/250107

Barro, R. J. (2001). Human Capital and Growth. American Economic Review, 91, 12-17.

Barro, R., \& Lee, J. (1994). Sources of Economic Growth. Carnegie-Rochester Conference Series on Public Policy, 40, 1-46. http://dx.doi.org/10.1016/0167-2231(94)90002-7

Borensztein, E., De Gregorio, J., \& Lee, J. W. (1998). How Does Foreign Direct Investment Affect Economic $\begin{array}{lllll}\text { Growth? Journal of International } & \text { Economics, } & 45, & 115-135 .\end{array}$ http://dx.doi.org/10.1016/S0022-1996(97)00033-0

Central Bank of Nigeria. (Various Issues). Annual Report and Statement of Account: Abuja.

Central Bank of Nigeria. (Various Issues). Statistical Bulletin: Abuja.

Cooray, A., \& Mallick, S. (2011). What explains cross-country growth in South Asia? Female education and the growth effects of international openness, The University of Manchester Brooks World Poverty Institute Working Papers 145. http://www.bwpi.manchester.ac.uk/resources/Working-Papers/bwpi-wp14511.pdf

Dollar, D., \& Gatti, R. (1999). Gender Inequality, Income and Growth: Are Good Times good for Women? Mimeograph. Washington CD: The World Bank. http://darp.lse.ac.uk/frankweb/courses/EC501/DG.pdf

Federal Ministry of Education. (2000). Implementation guidelines for the Universal Basic Education (UBE) Programme Abuja: Federal Ministry of Education. 1-17

Federal Office of Statistics. (1995). A Statistical Profile of Nigerian Women. Lagos.

Federal Office of Statistics. (Various Issues). Annual Abstract of Statistics: Lagos, Nigeria.

Galor, O., \& Weil, D. N. (1996). The Gender Gap, Fertility, and Growth. American Economic Review, 86, 374-387.

Herz, B., \& Sperling, G. B. (2004). What Works in Girls' Education: Evidence and Policies from the Developing World. Council on Foreign Relations, USA.

Hill, A., \& King, E. M. (1995). Women's Education and Economic Well-being. Feminist Economics, 1(2), 1-26. http://dx.doi.org/10.1080/714042230

Klasen, S. (1999). Does Gender Inequality Reduce Growth and Development? World Bank Policy Research Report Working Paper No. 7. Washington, DC: The World Bank

Klasen, S. (2002). Low Schooling for Girls, slower Growth for All? World Bank Economic Review, 16, 345-373. http://dx.doi.org/10.1093/wber/lhf004

Klasen, S., \& Lamnna, F. (2008). The Impact of Gender Inequality in Education and Employment on Economic Growth in Developing Countries: Updates and Extensions Paper presented at the World Bank conference http://www.eudnet.net/download/wp/EUDN2008_10.pdf

Knowles, S., Lorgelly, P. K., \& Owen, P. D. (2002). Are Educational Gender Gaps a Brake on Economic Development? Some Cross-Country Empirical Evidence. Oxford Economic Papers, 54, 118-149. http://dx.doi.org/10.1093/oep/54.1.118

Lagerlof, N. (1999). Gender Inequality, Fertility, and Growth, Mimeographed, Department of Economics, University of Sydney National Bureau of Statistics (2009) Social Statistics in Nigeria, Abuja Odusola, A.F. (1998) Human Capital Investment and the Empirics of Growth in Nigeria In.: Aigbokhan, B.E. Rekindling 
Investment for Economic Development in Nigeria. Conference Proceedings of the Nigerian Economic Society, 257-272.

Okojie, C. E. E. (1995). Human Capital Formation for Productivity Growth in Nigeria. The Nigerian Economic and Financial Review, 1(1), 44.

Okonjo-Iweala, N., \& Osafo-Kwaako, P. (2007). Nigeria's Economic Reforms: Progress and Challenges. Working Paper No 6, Global Economy and Development Program, The Brookings Institution. http://www.ancien.inter-reseaux.org/IMG/pdf_Nigeria_Economic_Reforms_Okonjo_2007.pdf

Sen, Amartya. (2000). Development as Freedom. New York: Anchor Books.

UNESCO. (2000). Women and Girls: Education; Not Discrimination, Paris: UNESCO. http://www.unesco.org/education/wef/en-press/press-kit_wome.shtm

UNESCO. (2002). Gender, Education and HIV/AIDS. Instituto Promundo, Rio de Janeiro: UNESCO.

World Bank. (2001). Engendering Development. Washington, DC: The World Bank.

Zaman, K. (2010). Do Female Enrolment Rates cause Economic Growth in Pakistan. Asian Social Science, $6(11)$. 